\title{
Eugenio Barba and Extra-Daily Scenic Behaviour: Influences of Stanislavski, Meyerhold and Grotowski ${ }^{*}$
}

\author{
Dila Okuş ${ }^{1}$ [e
} master dissertation titled "Extra-Daily Stage Behaviour: Actor Training at Odin Theatre" which I completed in 2020 in the Kadir Has University, School of Graduate Studies, MA Program in Film and Drama.

'Researcher, Kadir Has University, Faculty of Art and Design, Theatre Department,

Istanbul, Turkey

\section{ORCID: D.0. 0000-0002-7477-1989}

Corresponding author/Sorumlu yazar: Dila Okuş,

Kadir Has University, Faculty of Art and Design, Theatre Department, Istanbul, Turkey

E-posta/E-mail: dilaokus@gmail.com

Submitted/Başvuru: 13.10 .2020

Revision Requested/Revizyon Talebi/:

31.10.2020

Last Revision Received/Son Revizyon:

31.10.2020

Accepted/Kabul: 26.11 .2020

\section{Citation/Atıf:}

Okuş, Dila "Eugenio Barba and Extra-Daily Scenic Behaviour: Influences of Stanislavski, Meyerhold and Grotowski" Tiyatro Eleştirmenliğive Dramaturji Bölümü Dergisi 31, (2020): 23-43.

https://doi.org/10.26650/jtcd.809806

\begin{abstract}
Three directors who influenced 20th century theatre, Konstantin Stanislavski, Vsevolod Meyerhold and Jerzy Grotowski, and they each conducted comprehensive studies on the position of acting through theatrical aesthetic. In order to realize this theatrical aesthetic, these directors emphasized the need for actors to practice systematic exercises and develop particular scenic behaviour, which is different from daily behaviour. Their work has paved the way for various theoretical studies on acting. The actor who is going to act within a reality that fictionalized on stage, no matter the strength of its relationship with daily reality, has to leave the automatized daily behaviour behind and develop a technique that is built upon the necessities of the stage context. In this article, the basis of the extra-daily scenic behaviour of actors in the Odin Theatre is dealt with in the light of approaches of directors who strongly affected the theatre approach that developed through the 20th century: namely Stanislavski, Meyerhold and Grotowski.
\end{abstract}

Keywords: Extra-daily, Eugenio Barba, Konstantin Stanislavski, Vsevolod Meyerhold, Jerzy Grotowski 


\section{Introduction}

Konstantin Stanislavski, Vsevolod Meyerhold and Jerzy Grotowski are directors who worked on the principles of scenic behavior of actors, and they influenced $20^{\text {th }}$ century theatre movements with their aesthetic approaches. While Eugenio Barba was developing his own method and approach, he was greatly influenced by the works of these directors. Therefore, to understand Barba's work and the principles of the scenic behavior of the Odin Theatre actors, it is necessary to reveal his relationship with these directors.

$20^{\text {th }}$ century theatre history is a period in which the tendency for directors to develop systematic acting methods and to put emphasis on acting exercises and laboratory work gained momentum. Konstantin Stanislavski argued that the creativity and talent of the actor can only become alive with disciplined techniques and he developed the first acting training method in Europe and North America. Thanks to Stanislavski and his followers, acting technique become the center of theatre renewal in the $20^{\text {th }}$ century. ${ }^{1}$ At the same time theatre directors became aware that the stage aesthetics that they were searching for could not be considered independent from acting, so they entered into a substantial study on acting methods and put forward extensive studies in the field. Meyerhold's production The Death of Tintagiles ${ }^{2}$ in the Theatre Studio of the Moscow Art Theatre established that the scenic behavior of the actor is an essential component of the staging technique of the director. Meyerhold understood that the actors who were educated in the psychological-realistic acting technique of the Moscow Art Theatre were insufficient to realize his targeted stylized aesthetic and he emphasized that each scenic form needed to have its own acting method. Stanislavski in the Opera Studio, Meyerhold in the Meyerhold Studio, Grotowski in his Laboratory, Barba in the Nordisk Teaterlaboratorium each conducted notable research on acting. Acting training is directly dependent on the director's research of staging form. All these directors had an aim and they worked on skills that need to be gained by actors in order to reach their aim. In line with their specific needs, at times they followed the previous work and at other times they separated from it. To understand the motivations of both followings and separations, acting works need to be discussed within the context of their relationships with each other. Therefore, the influence of the works of Stanislavski, Meyerhold and Grotowski, on the development of extra-daily stage behavior in the Odin Theatre will be discussed in the context of their thoughts on the function of the theatre, the relationship between daily reality and the stage and the method of acting developed consequently.

Alison Hodge, Actor Training (New York: Routledge, 2010), xviii.

2 For detailed information of the production process see Vsevolod Meyerhold, Meyerhold on Theatre, Ed. Edward Braun (London: Bloomsbury Methuen Drama: 2016), 45-57. 
Eugenio Barba, the founder and the director of the Odin Theatre, states that stage behavior of the actor is based on an extra-daily technique. The term 'extra-daily' is used to refer to the scenic behavior seen mostly in Eastern coded performing forms. The technique requires the actor to move on the stage with the exactly the opposite rules that s/he would use in daily life. In this technique acting principles, which are consistent in it, are equivalent to the habitual practices but different from them. At the basis of this technique is the effort to create an alienated situation on the stage, which is a fundamental characteristic of art, according to Barba. However, the actor should be able to create a consistent language to have an effect on the spectator. Consistency is necessary to make the fictional meaningful. In all fictionalized performing forms, depending on the aesthetic structure of the performance, actors use extradaily scenic behavior. In a fictionalized world on the stage, actors need to use a different kind of energy than that in daily life. Even if the representation of daily reality is the final aim of the performance, fictionalization of the reality makes the actors' behavior extra-daily. While the distance between daily reality and the scenic reality increases, the extra-daily technique of the actor deepens its roots. In this article, the influences of the works of Konstantin Stanislavski, Vsevolod Meyerhold and Jerzy Grotowski on extra-daily scenic behaviour will be discussed.

\section{Function of the Theatre}

Scenic techniques and acting methods developed by directors are directly related to their approaches on the function of the theatre. To begin discussing the effects of Stanislavski, Meyerhold and Grotowski's works on the extra-daily technique of Barba's theatre, comparing their approaches on the function of the theatre could provide a helpful basis to understand the practical dimension of the methods.

For Stanislavski, Meyerhold, Grotowski and Barba, it is possible to say that the main function of the theatre is like a way of attaining the truth of life, as a part of the philosophical pursuit of contemporary theatre thought. The search for a better life and the desire to become a happier person underlie this pursuit. Stanislavski believes that the truth is hidden in the details of daily life that are stripped of the banality and tries to emphasize these details in his staging. Thus the actors need to live these details on the stage spontaneously just as they do in daily life, to make the spectator believe in her actions and share the truth between the actor and the spectator. Meyerhold on the other hand argues that truth can only be captured in the language of theatre, not in the language of daily life. Truth will not appear elsewhere but within the reality fictionalized by the theater. For this reason, a stage language that can only be set up with theatrical tools can contain truth. ${ }^{3}$ On the stage the actor should adopt a theatrical reality language as a way of behavior, not the codes of behavior of daily reality, and s/he should gain skills to express herself/himself in this language. Grotowski on the other

3 Meyerhold, Meyerhold on Theatre, 81. 
hand, thinks that everyday reality, the state of socialization, conceals the truth and that the truth will emerge in the shared space between the actor and the spectator when reaching the total act. ${ }^{4}$ Actors should train themselves to achieve the total act by transferring the stimuli that are composed of associations into reactions. Barba thinks that the truth appears when situations related to daily reality are recreated on stage by stripping them of daily cultural codes. The recreation of actions from daily life with an extra-daily behaviour has a possibility of achieving a truth about the universal human state. Barba emphasizes the common aspects of the human condition and attempts to provide both actor and the spectator with an experience of this commonality on a level of artistic reality. In the field of Theatre Anthropology ${ }^{5}$ research, the activity aimed at discovering the commonalities in the scenic behaviours of the performers in coded performance forms is a method followed to achieve this goal. Barba believes that habitual behaviour is shaped by cultural codes and the shared commonality beyond the cultural is truth. Barba shares Grotowski's view that modern life causes division and that this division can be overcome by the discovery of the primitive un-socialized state of humans. However, as a method, he emphasized the importance of the power that theatre has as a form, unlike the Grotowski's view in his later years of work, in which the distinction between theatre and life should disappear. In that sense, it is possible to say that Barba is closer to the view of Meyerhold who emphasizes the power of the potential of what is theatrical. The 'system' of Stanislavski as a method of creating a fictionalized reality on the stage is important for Barba at this point. The scenic reality, contrary to Stanislavski's intention, moves away from the daily reality; nevertheless the principles of fictionalizing reality proposed by Stanislavski provide a modal for Barba to build performance.

\section{Actor in The Center}

In the work of these directors, the actors are central and each of the directors developed an acting theory to serve their own aesthetic pursuits. The actor's work of developing a scenic behavior is part of the director's work of developing the theatrical instruments with the necessary qualifications to achieve the aesthetics at which s/he aims. Building the actor's scenic behavior is the development of the acting tool to serve the purpose of the scenic technique. The most basic way of the performer to gain the necessary abilities is to do exercises in actor

4 Eugenio Barba, "The Theatre's New Testament” in Towards a Poor Theatre, Ed. Eugenio Barba (New York: Routledge, 2002), 34.

5 With an intercultural research perspective, Eugenio Barba'a study of the principles of the actor's stage life developed together with artists and researchers such as Nicola Saverese, Fernando Taviani, Sanjukta Panigrahi and led to the birth of the field of Theatre Anthropology and ISTA (International School of Theatre Anthropology). In this research, artists and researchers from different parts of the World, form the East and the West come together and discuss and conduct studies sharing their experiences. The findings of this study are shared in these books; Dictionary of Theatre Anthropology: Secret Art of The Performer (E. Barba, N. Savarese), The Paper Canoe: The Guide to Theatre Anthropology (E. Barba) and Thinking with the Feet (ed. Anne Vicky Cremona, Francesco Galli ve Julia Varley) ve The Five Continents of Theatre: Facts and Legends about the Material Culture of the Actor (E. Barba, N. Savarese). 
training. Extra-daily technique requires exactly the opposite of automatic and spontaneous daily behavior so exercises are critically important to intervene in the daily automatism. Most of the $20^{\text {th }}$ century western directors who have focused on actor training have developed their exercises upon the Stanislavski's idea that the creativity can be activated in a systematic way. Creative state of mind of the actor that Stanislavski aimed to reach has a similar basis as Meyerhold's reflex excitability, Grotowski's stimulation of the organism with associations and Barba's pre-expressive level. All these concepts indicate the physical and mental situation of the actors' scenic behavior. Stanislavski claimed that the actor can enter the scenic presence not accidentally, but by conditioning herself with certain exercises. The 'system' becomes fundamental because it is a systematic guide to the actor to present scenic behavior. Stanislavski built his theory of acting, which is a requirement of the theatre thought he believes in, using a methodological approach. Meyerhold, Grotowski and Barba also tried to put forward the principles of the scenic behavior of the actors using a methodological approach in order to express the theatrical thought they followed. The common thought emphasized by all of these directors, starting with Stanislavski, is that the actor should carry out intensive and systematic training in order to gain the scenic behavior. Stanislavski revealed a systematic acting method as a result of his research. His student Meyerhold had the opportunity to conduct research on his own aesthetic search in Stanislavski's studios, and shaped his approach by opposing his psychological realist understanding. ${ }^{6}$ Grotowski started his work from the point where Stanislavski left off. Furthermore, in addition to the formal discipline that he emphasized, Meyerhold's idea that the actor's training should be in composition logic formed the basis of his work. Barba, who worked as Grotowski's assistant, followed on from Grotowski's exercises, especially when setting the framework of the actor training. In addition, Richard Cieslak, the actor following Grotowski, had workshops for Odin Theatre actors. ${ }^{7}$ Moreover, it can be thought that Meyerhold's efforts to cause the actor's physical activity to effect the senses of the spectator had an impact upon Barba's tendency to allow the scenic behavior of the actor to have an effect on the spectator's kinesthetic senses.

\section{Stanislavski, 'system' and Physical Action Method}

Konstantin Stanislavski is the director who conducted the first comprehensive and methodological study on the scenic behavior of the actor. The Stanislavski 'system' is a written source that develops a holistic approach to the art of theatre and offers a systematic method for acting. In addition to being the master of the current practitioners of Stanislavski's pscho-physical acting technique, his apporach on actor training is the starting point for different techniques. Rose Whyman summarises two questions that Stanislavski tried to answer throughout his life as follows: "How the actor can infuse a role with emotional or spiritual content, and

$6 \quad$ Meyerhold, Meyerhold on Theatre, 51.

7 Fragments From Training at Teatr-Laboratorium, Director Torgeir Wethal, (Holstebro: Odin Teatret Archives, 1972). 
how s/he can repeat a performance without it tired and mechanical?" The reason for these questions is the search for truth in the actors who can establish the organic life contrary to the teatricality that destroys life on the stage. ${ }^{9}$ Stanislavski aims to recreate the reality of the daily life on the stage in a consistent and organic way. Stanislavski's aesthetic preferences are determined by his thoughts on the function of the theatre. He believes that theatre has the following function: "to civilise, to increase sensitivity, to heighten perception". ${ }^{10}$ So he adopts the principle of realism:

The best method of achieving this end was adherence to the principles of Realism. This was more than a question of aesthetic preference or a predilection for one 'style' over other 'styles'.... Stanislavski was implacably opposed to meaningless conventions to 'Theatre' in the theatre, which he hated. He was no less opposed, later in life, to the experiments of the avant-garde, which he considered reduced the actor to a mechanical object. Dehumanised actors lead to dehumanised perceptions. ${ }^{11}$

Stanislavski takes a non-banal realism approach on the stage. According to him, elements worth telling from daily life should be chosen on the stage and combined with theatrical composition logic. Being realistic on the stage does not mean to bring the ordinariness of daily life to the stage as it is. Stanislavski considers this kind of realism to be "banal". ${ }^{12}$ While looking for the truth of the actions, he expresses that they are accused of being naturalistic and at the point where they do this, he finds himself wrong. ${ }^{13}$ For him, realism is a way of emphasizing the unique elements of life and he aims to include these in the historical and social essence of the characters. He says unless he can do this, he unintentionally becomes naturalistic. ${ }^{14}$ Stanislavsky argues that the truth of the life should be represented on the stage within certain rules and life on the stage should be expressed in an artistic form. ${ }^{15}$ The life created on the stage should be poetic. Truth on the stage is constructed through the actions that the actor performs in a manner that is formally similar to daily reality. However, Stanislavski insistently emphasizes that stage reality is fiction.

To create true life on the stage, the actor needs to have a sense of artistic and organic truthfulness. The organic life on the stage is dependent on the actor's belief in the scenic reality,

8 Rose Whyman, Stanislavsky System of Acting, Legacy and Influence in Modern Performance (New York: Cambridge University Press: 2008), 1.

9 Stanislavski criticizes the representational acting in the tsarist theatres of the period on the ground that it could not create a true life on the stage.

10 Jean Benedetti, Stanislavski: An Introduction (New York: Routledge, 2005), 16.

11 Ibid., 16.

12 Konstantin Stanislavski, "Stanislavski'nin Mirası", trans. Metin Göksel and G. Ahıskanlı, Mimesis Tiyatro/ Çeviri-Araştırma Dergisi 3 (1990), 138.

13 Nikolai M. Gorchakov, Stanislavski Directs (New York: Minerva Press, 1954), 43.

14 Benedetti, Stanislavski: An Introduction, 17.

15 Konstantin Stanislavski, An Actor Prepares, trans. Elizabeth Reynolds Hapgood (London: Bloomsbury Publishing, 2014), 32 . 
and s/he needs to have faith and a sense of truth as stated in the book An Actor Prepares ${ }^{16}$. The actor should have "a sense of truthfulness... and a feeling of believing in all physical objectives" ${ }^{17}$. The actor should sincerely believe in the scenic reality. The difference between daily reality and scenic reality also differentiates the sense of faith in both. While the first one is "created automatically", the second one "originates on the plane of imaginative and artistic fiction". ${ }^{18}$ Stanislavski expects the actor to believe in the reality of what is happening on the stage on behalf of the character and thus convince the audience. He uses the magic if in order to awaken the faith and a sense of truth in the actor. The actor asks, "What would I do if I were..." ${ }^{19}$ to himself/herself and creates a fictional reality with the magic if. The actor, who uses the magic if, should build the given circumstances and $\mathrm{s} /$ he should consider the given circumstances as his/her own limits and perform physical actions under these conditions. This road map, which is the basis of the system, presents the framework of the steps, which should be followed by the actor while building the scenic reality. The magic if indicates fictionalized reality and the given circumstances determine the limits of it.

Another point that makes Stanislavski essential is his emphasis on the moral suggestions that he actor must adhere to. The actor should develop an approach that puts the character and the actions in the foreground, not him/herself in order to get the most effective result from the 'system'. The fact that the actor should approach his/her acting work with a certain ethical attitude has also been important for directors after Stanislavski. Both Grotowski's and Barba's emphasis on going beyond the limits, serves to enable the actors go beyond their daily behaviour and thinking. A focus on work rather than on their own fatigue; enables them to prioritize their work, not their own selves. This means that they develop the attitude necessary for the training or the rehearsal to yield results. Stanislavski's conduct of his work on an observable and experimental ground, the way he gets involved and sets the work up with a laboratory perspective, have all become a model for Meyerhold, Grotowski and Barba's actor training. The physical action method, which is the final phase of Stanislavski's work on the 'system', is a fundamental study for the acting methods developed in the following years in terms of emphasizing putting the action in the centre while developing the scenic behaviour for the actor.

Among the theatre approaches discussed within the scope of this article, the most similar scenic behaviour to the daily behaviour on the stage appears in Stanislavski's theatre. However this formal similarity does not mean that the actor's behaviour carries an everyday banality. The actor's scenic behaviour should be spontaneous, just like in daily life, yet this spontaneity should belong to the stage, and it should emerge as a result of a detailed study of the rules of scenic behaviour. Stanislavski sought a way for the actor to repeat the spontaneous behaviour

16 Ibid.

17 Ibid., 155.

18 Ibid., 156.

19 Sonia Moore, The Stanislavski System, The Professional Training of an Actor (New York: Penguin Books, 1984$), 40$. 
that a person exhibits in daily life without becoming mechanical. Actions must maintain the same liveliness on the stage with each repetition. In daily life this is not possible, however with the 'system', the actor learns how to do that. Stanislavski's quest in art is the search for an acting method that will make repetition on the stage alive each time, and different from daily life. The techniques applied by Stanislavski in the process of reaching the subconscious by means of consciousness, as well as concepts such as the magic if, given circumstances, faith and a sense of truth, and organicity all serve the purpose of staging a fictional reality that takes the character into the centre with a realistic approach. In this sense, Stanislavski's method for building fiction preserves its validity even for theatre people who do not claim to be the practitioners of the 'system' and deny the legitimacy of realism on the stage. The methodological approach he developed constitutes an important starting point in the development of extra-daily technique.

\section{Meyerhold, Stylization and Biomechanics}

Meyerhold's theatre, actor training and stage aesthetics approach is based on stylization. He aims to establish a reality that belongs to the theater on the stage. He explores ways of constructing the theatrical in the contemporary stage by using the means of traditional theatre. As a part of this research the actor needs to develop a scenic behaviour through conditioning herself/himself with biomechanical exercises. Stanislavski looks for the truth of reality on the stage, but Meyerhold, while art is looking for truth, it should not imitate the reality in somewhere else but create its own. ${ }^{20}$ Meyerhold is Stanislavski's student; he trained in his studios and acted in his plays. Besides these qualifications, he thought that the psychological-realistic approach, in his terms the naturalistic approach, is restrictive and it is insufficient to answer the needs of contemporary theatre thought. In his staging works, he adopted a symbolist $\mathrm{t}^{21}$ understanding that could be an alternative to naturalist $\mathrm{t}^{22}$ aesthetics. He has a solid knowledge of the method of applying the realistic approach on the stage and with this knowledge he attempts innovative trials against it. These trials have led to the emergence of the biomechanics, which enables the actor's exercises on the stage to set aside the rules of daily reality in every sense and develop a new way of behaviour. Meyerhold's efforts at developing a language of the theatre and a proper acting style has been a source of inspiration for many directors, including Barba. Meyerhold's search for form in the theatre is driven by the assumption that the rational representation of daily reality on the stage is not enough to understand the truth of life and to tell the essence of the play. The truth of life is hidden in the essence of the situation and emotions in the play,

20 Marjorie L Hoover, Meyerhold: The Art of Conscious Theater (Amherst: University of Massachusetts Press, 1974), 1.

21 Nick Worral, Modernism to Realism on the Soviet Stage (New York: Cambridge University Press, 1989$) 4$.

22 Stanislavski defines his theatrical approach as realistic, not naturalistic. However, in the book Meyerhold on Theatre and in other sources written on the Meyerhold theatre, the Works of Art Theatre are described as naturalistic. 
and it will only be possible to reveal the elements in the essence of the play by applying the laws of theatre on the stage and using theatrical tools. In order for theatre to tell the essence of life, art must get rid of its old realist form and put its new means into action.

Meyerhold's theatrical aesthetics is strictly committed to his thoughts on the function of the theatre, the political developments of his era and his political stance. He thinks that the realist aesthetics that shape Stanislavski's scenic life formally resembles the theatres criticized by Stanislavski himself and he finds this form obsolete. He thinks that realistic aesthetics is not enough to understand and explain the new world. For Meyerhold, naturalistic aesthetics is "a bourgeoisie aesthetics", in the sense that it does not consider the demands of the party nor the audience. Meyerhold's work before the revolution "focuses on developing an alternative aesthetic to artistic reality and building a new acting technique"23. After the revolution, he frequently emphasized that he tried to observe the interests of the new audience, that is the people who wanted "to know precisely why a play is being performed and what the director and actors are trying to say in it". ${ }^{24}$

Meyerhold thinks that the pursuit of reality is a futile quest to achieve an aesthetic effect in contemporary theatre. It is impossible to create an exact representation of reality on the stage, so reality must be schematized by the possibilities of theatre. Meyerhold seeks a new form of expression that can best convey the essence of the play to the audience:

To 'stylize' a given period or phenomenon means to employ every possible means of expression in order to reveal the inner synthesis of that period or phenomenon, to bring out those hidden features which are to be found deeply embedded in the style of any work of art. ${ }^{25}$

The art of stylization requires working with a simple approach where the actor is centred, leaving aside the complex stage arrangements. In stylized theatre, the aim is not the rational representation of reality through actions, but the creation of a new stage reality. The actor must develop a new behaviour on the stage that will emphasize the phenomenon and feelings that are the essence of the play. Stylization is a strong way of expression to express the inner senses. Meyerhold thinks that in order to understand a situation or emotion, symbols must be staged to reveal their hidden meaning. In that sense he puts movement before words. While looking for ways for the actor to develop scenic behaviour, he turned to traditional forms and Eastern coded performance forms. The actor of the new theatre, which has the capacity to perform the aesthetic that Meyerhold is looking for, must have full knowledge of the technical possibilities by "studying the principles of acting from the truly theatrical ages of the theatre" 26 . For this reason, he looked at the foundations and origins of theatre in order to find the essence of art

23 Kerem Karaboğa. Oyunculuk Sanatında Yöntem ve Paradoks (İstanbul: Habitus Yayıncılık, 2018), 147.

24 Meyerhold, Meyerhold on Theatre, 317.

25 Ibid., 49.

26 Ibid., 181. 
both in his actor training and while creating the new theatre language. Besides Ancient Greek Theatre and Commedia, he researched traditional Asian Theatre forms like Kabuki. Instead of bringing traditional means of theatrical expression to the stage as they were, he sought to explore their meaning for the contemporary theatre.

The actor's body is an extremely important theatrical tool for Meyerhold. The actor should prepare his body for the most efficient use by practising biomechanical exercises. The purpose of the biomechanical exercises is to benefit from "maximum exploitation of the expressive power of movement" 27 . The exercises (etudes) developed within the scope of the biomechanical method teach the actors the basic principles of scenic behaviour and provide a modal for actor training. The main training points are the actor's development of awareness of the place s/he is in, working with objects and strengthening the relationship between partners. Exercises are carried out on the actor's relationship with gravity and balance. In the etudes, daily actions are segmented and a detailed study is carried out on the basic features of each part. ${ }^{28}$ With the etudes, Meyerhold aims to create a specific system that will cover all the basic narrative situations that the actor may encounter on stage. ${ }^{29}$ All the principles serve the purpose of developing a holistic physical behaviour skill on the stage.

The actor who is involved in Meyerhold's aesthetic quest must develop a precise formal discipline in the scenic behaviour. He emphasizes the importance of exercises for the actor to gain such a qualification. His attitude of constructing actor training under the roof of a studio is modelled from Stanislavski's way of research. Meyerhold is also in a search for a formal discipline in the whole performance. In this sense, his approach to the performance as a musical composition was the source of Barba's idea that the performance includes different levels of organization. In Meyerhold's acting work, the emphasis on the necessity of the whole body behind an actor's movement, his development of exercises that train the actor to gain this ability and his emphasis on the movement-based sensory communication between the actor and the spectator have contributed to the level of organic dramaturgy ${ }^{30}$ in the Odin Theatre. Meyerhold's approach of that explaining the essence of the play with the acting tool can only be possible by leaving daily behaviour aside and this has led his work towards an extra-daily acting technique. His experimental work was supported in the revolution period of Russia in terms of meeting the needs of the modern world, but his experimentation became a threat to the

27 Ibid., 399.

28 For a documentary on biomechanical etudes and its principles see Meyerhold's Theatre and Biomechanics, 1999, Mime Center Berlin, Gennadi Bogdanov, Jörg Bochov, Thilo Wittenbecher.

29 Alma Law and Mel Gordon, Meyerhold, Eisenstein and Biomechanics: Actor Training in Revolutionary Russia (Jefferson: McFarland\&Company: 1996), 26.

30 In the Eugenio Barba's productions, the performance is composed of different levels of organizations. Orgaic dramaturgy defines the work of the actor. For detailed information, see Eugenio Barba. On Directing and Dramaturgy, Burning the House, trans. Judy Barba (New York: Routledge, 2010). 
established order due to the changing political conditions during the Stalin period. Meyerhold's works should not be perceived only as a formal search since he revealed a way of perceiving the world with stylization. In his artistic pursuit, he set aside the rational representation of reality and pursued the construction of a new reality and in his work biomechanics, he aimed to get rid of the daily behaviour of the actor and create a scenic behaviour. Therefore, it is possible to say that he has developed an important methodological study for the extra-daily acting technique.

\title{
Grotowski, Poor Theatre and Total Act
}

In the theater work that Grotowski carried out throughout his life, he sought ways to overcome the division and alienation that civilization creates on the individual and the obstacles that socialization puts before truth. He claims that the daily and natural behaviour of the civilized individual obscures the true state of a human being. According to Grotowski, the behaviour displayed in social life is masked by civilization and is therefore not real. The truth can only be achieved by getting rid of these masks. The actor must develop a theatre-specific manner of behaviour in order to reveal the truth overshadowed by daily behaviour on the stage. The scenic behaviour Grotowski developed with the actors aims to liberate them from these obstacles. The actions of the actor aiming to be freed from natural behaviour have an extra-daily quality.

Grotowski thinks that theatrical activity has the potential to reveal the truth. In theatre, this potential can be realized only by using its unique form of communication. The main question that Grotowski sought an answer to within the art of theatre is regarding the peculiar feature of what theatrical activity is. In this sense, his work is mainly the investigation of the actorspectator relationship and he emphasizes that they "consider the personal and scenic technique of the actor as the core of the theatre art". ${ }^{31}$ The most important distinctive feature of the theatre is that it allows the actor and the audience to coexist. The study to be conducted should explore the possibilities of this relationship. The idea of Poor Theatre is a result of this approach:

\begin{abstract}
By gradually eliminating whatever proved superfluous, we found that theatre can exist without make-up, without autonomic costume and scenography, without a separate performance area (stage), without lighting and sound effects, etc. It cannot exist without the actor-spectator relationship of perceptual, direct, "live" communion. ${ }^{32}$
\end{abstract}

In order for the actor to develop a scenic behaviour different from daily life, s/he must be freed from the domination of mind, physically liberated and reach a spontaneity in which inner impulses are expressed in outer reactions. However, this spontaneity is different from the automatization exhibited naturally; it is a behaviour that will enable true reactions to

31 Jerzy Grotowski, "Towards a Poor Theatre" in Towards a Poor Theatre, Ed. Eugenio Barba (New York: Routledge, 2002), 15.

32 Ibid., 19. 
occur. Grotowski is not interested in daily actions because daily actions continue to hide the person as in everyday life: "Our daily efforts are intended to hide the truth about ourselves not only from the world, but also from ourselves". ${ }^{33}$ Grotowski seeks for exact openness and confrontation. In this sense it is not a coincidence nor a preference that the actors' scenic behaviour is extra-daily, but rather it is a necessity for his search. For an actor to reach the total act $\mathrm{s} /$ he should have a distance from a social way of thinking and behaving. S/he should have a series of exercises that will ensure that the associations turn into stimulus on the body and turn these stimuli into reactions. The exercises basically enable the body and the mind to allow the inner impulse to transform into outer reaction spontaneously. In order to be creative, the actor must develop a method to stimulate the self-revelation process and eliminate the obstacles and resistances. ${ }^{34}$ The actor should get rid of daily resistance, go beyond the limits of daily life and through concentrating on the process of self-knowledge, develop the ability to transform inner impulse to outer reaction. The way of developing this skill is "via negativa" which means reduction. The actor should not collect skills; on the contrary s/he should eliminate them. The actor must develop an inductive technique and eradicate the blocks so that the impulses can freely turn into outer reactions. ${ }^{35}$ Exercises aiming to develop a scenic behaviour do not restrict the behaviour pattern of the actor; on the contrary, they develop the ability to use all the possibilities they have and prepare the ground for him/her to release creative stimulations. In order to talk about the total act, the spontaneous state in which consciousness is disabled and the physical discipline in which the actor is competent must be together. In his studies, Grotowski turned to the sources of theatre and to the combination of formal discipline and spontaneity. In Indian Kathakali or Balinese performances he observed that spontaneity and discipline reinforce each other and this togetherness was inspiring for him. ${ }^{36}$ To advance this study, in his Theatre of Sources ${ }^{37}$ he conducted a research into the roots that lie at the base of various theatrical cultures during the period. His purpose was not to take and apply mere techniques of Eastern forms directly. His concern was to discover the principles on which the formal discipline is based, with a transcultural group. Grotowski's method is built upon a combination of Stanislavski's approach on actor training, his physical action method and separation of the actor's exercises and work of production, and on Meyerhold's proposition that "the entire body should involve the movement" 38 . These are all important discoveries and arguments developed by Grotowski. The unity of the working principles of these two theatre people forms the basis of Grotowski's approach:

33 Barba, "The Theatre's New Testament", in Towards a Poor Theatre, 37.

34 Grotowski, "Methodical Exploration", in Towards a Poor Theatre, 128.

35 Barba, "The Theatre's New Testament", 34-35.

36 Grotowski, "He Wasn't Entirely Himself", in Towards a Poor Theatre, 121.

37 For detailed information about the period see Jane Kumiega, The Theatre of Grotowski (New York: Methuen, 1985).

38 Karaboğa, Oyunculuk Sanatında Yöntem ve Paradoks, 82. 
Meyerhold based his work on discipline, exterior formation; Stanislavski on the spontaneity of daily life. These are, in fact, the two complementary aspects of the creative process. ${ }^{39}$

Grotowski received the elements to ensure the organicity of the action from Stanislavski, yet the purpose of his study is unlike Stanislavski's who tried to create a realistic life on the stage, making the person performing the action to find the impulses in the basic flow of life. In order for the actor's action to be real, it must be executed in connection with impulses. Otherwise, the movement is nothing more than an activity. Grotowski defines the impulse as: "begins inside the body and which is visible only when it has already become a small action". ${ }^{40}$ At the root of every physical action is an impulse that repeals it, and it is this impulse that prevents the action from becoming ordinary. This detailed work carried out by Grotowski on the impulses led to the greater identification and role of impulse in the work carried out on the actions at the Odin Theatre. Grotowski's exercises with the actors significantly affected Barba's work because he witnessed this process as Grotowski's assistant. Although Grotowski's work with the actors in the latter period of his work put aside the research conducted on audience participation, it is still constructed as open to the theatre groups or researchers. Sharing of the working process and the ongoing acting research with the public in the concept of laboratory logic has shaped the approach at the Odin Theatre. The laboratory approach is executed in Odin Theatre through the "work demonstrations" of the Odin actors. Another important interaction in terms of the Grotowski and Barba relationship is that Barba, who worked with Grotowski during the period of Theatre of Sources, continued his work under the roof of the Odin Theatre and his studies opened up the field of Theatre Anthropology.

Grotowski's efforts to reach the true state of human beings and the method he developed in his theatre activity evolved and developed throughout his life. Putting the actor at the centre of theatre work and an effort to systematize actor training in connection with his search for the function of the theatre is the greatest proof that he furthered Stanislavski's legacy. The work followed through by the actor as a civilized individual in order to find the truth in the essence of his/her daily life gave rise to the necessity of developing an extra-daily scenic behaviour. In this sense, Grotowski's approach towards actor training to develop an extra-daily scenic technique reveals a consistent framework for the strong relationship between functional value and methodological means of the theatre.

\section{Eugenio Barba, Odin Theatre and Theatre Anthropology}

Eugenio Barba was Grotowski's assistant in Poland for three years before founding the Odin Theatre in Norway in 1964. This experience significantly affected his approach to theatre. Traces of Grotowski's work are clearly visible in the basis of Barba's understanding of theatre.

39 Denis Bablet, "Actor's Technique" in Towards a Poor Theatre, 209.

40 Thomas Richards, At Work With Grotowski on Physical Actions (London/New York: Routledge, 1995$), 93$. 
Grotowski is not only theatre person who Barba recognizes as his "master". During the studies in the field of Theatre Anthropology, he also examined the directors who influenced Western theatre in the $20^{\text {th }}$ century and was significantly influenced by the methods and approaches they developed. In the article "Grandfathers, Orphans, and the Family Saga of European Theatre", Barba describes Stanislavski and Meyerhold as his grandfathers and Grotowski as his older brother. ${ }^{41}$ The primary factor that makes these directors important for Barba is that they carried out a detailed and systematic study on the scenic life of the actor, although the results they want to achieve are different. Stanislavski's finding that the actor can reach the creative state by making use of psycho-physical exercises with the assumption that $\mathrm{s} / \mathrm{he}$ will reach the magic if is extremely important. Achieving the creative state for the actor means different things for Barba and Stanislavski, but it is the main goal of the actor training in the theatre of both directors. Meyerhold's biomechanics sets out the principles of the actor's scenic life with a series of exercises and develops the bodily practice that will enable the actor to acquire scenic behaviour. Moreover it is possible to claim that Meyerhold's idea of combining the actor's text and gestures independently from each other as a musical composition influenced Barba's montage technique.

The reason why these directors who shaped the $20^{\text {th }}$ century theatre were also a source of inspiration for Barba was not only that they offer ways of how the actor can be effective on the stage, but that they also develop an approach as to why, where and for whom to be effective. ${ }^{42}$ Barba's theatrical aesthetic is shaped by the pursuit of truth beyond human behaviour which in turn is shaped by cultural values. Natural and automaticised behaviour in daily life is cultured behaviour. Cultured behaviour and cultural prejudice hide the truth. The destruction of these prejudices is only possible with the discovery of commonalities regarding the human condition, so the technique to be developed on the stage serves to overcome this obstacle. Extra-daily technique is based on the emphasis of the actor's behaviour on the stage, which is different from the daily behaviour. The fact that the spectator can be a part of a sharing space based on a communication code other than daily reality communication codes indicates that human beings have a commonality beyond daily reality. In this sense, it is possible to say that the political value of art and theatre stems from the opportunity to open such a space. The extra-daily nature of the technique is based on the physical rules by which the action is performed rather than the rational meaning. Performing the actions, which already have a certain meaning for the spectator, with an extra-daily technique, interferes with the way they view these actions and the way they experience them. The extra-daily technique allows rethinking how culture filters one's behaviour, to develop a self-critical view of the behaviour shaped within the culture, and to intervene in the habituated behaviour pattern in daily life.

41 Eugenio Barba, "Grandfathers, Orphans, and the Family Saga of European Theatre", New Theatre Quarterly 19/2 (2003). 108.

42 Eugenio Barba, "The Essence of Theatre" TDR (1988-) 46/3 (2002), 12. 
Extra-daily technique is based on the principles of scenic behaviour called recurring principles. ${ }^{43}$ The recurring principles are based on the field of Theatre Anthropology, which examines the commonalities between the principles of performers' scenic behaviour. The research area of Theatre Anthropology is shaped around the question of "where can performers find out how to construct the material bases of their art" 44 and examines the scenic behaviour of the performer, which is shaped in line with the principles which are different from daily behaviour. In this field of research, the commonality of the behavioural principles of actors in different performance styles has been examined. Studies in Theatre Anthropology reveal that in the scenic behaviour of the actor, unconscious and spontaneous daily behaviour is replaced by a conscious and determined behaviour. The foundations of the actor's scenic life are shaped within the framework of the principles set forth from the findings of an intercultural study. Both Eastern and Western forms are examined. The subject of the examination is the principles on which forms are built. In this approach Barba refers to the Etienne Decroux's observation, the only master in the West who put forward the "system of rules comparable to that of an Oriental tradition", that arts resemble each other not with their works but with their principles. ${ }^{45}$ The behavioural principles set in the Oriental/Eastern forms are often more specific, and these determined behavioural principles allow the actor to get rid of daily automatism and take into account the use of energy during the performance. These principles of behaviour form the basis of the extra-daily technique that Barba emphasizes as the basis of the scenic presence. ${ }^{46}$ The recurring principles of balance, opposition, equivalency, and transposition are revealed by this research based on the discovery of commonalities and they present the physical limits of the extra-daily scenic behaviour. This limitation bears resemblance to the framework proposed by Stanislavski with the magic if and given circumstances. Just as Stanislavski's actor restricts her/himself in the psychological framework of the given circumstances of the character while performing the action, Barba's actor limits her/himself within the framework of the principles of physical behaviour imposed by recurring principles while performing the action. Barba states that Stanislavski conducts one of the most comprehensive studies on how to construct scenic life by separating the scenic behaviour of the actor from daily behaviour. ${ }^{47}$ Stanislavski describes the scenic life of the actor as second nature. The scenic life of an actor is different from daily life which means s/he follows different rules from those of daily behaviour while moving on the stage. This rule is applied even to the state when the actor is on the stage but not at the level of expression. Barba describes this level as the pre-expressive level and he

43 For detailed description of reccuring principles see Eugenio Barba, The Paper Canoe: A Guide to Theatre Anthropology, trans. Richard Fowler (New York: Routledge, 2002).

44 Eugenio Barba and Nicola Savarese, Dictionary of Theatre Anthropology: Secret Art of The Performer, trans. Richard Fowler (London: Routledge, 2006), 6.

45 Ibid., 7-8.

46 Ian Watson, "Eastern and Western Influences on Performer Training at Eugenio Barba's Odin Teatret". Asian Theatre Journal 5/1 (1988), 54-55.

47 Eugenio Barba, "Letter From Barba", The Drama Review: TDR 19/4 (1975), 47-57. 
claims that the existence of this level in acting is common in all cultures. ${ }^{48}$ To understand extra-daily techniques, it is necessary to realize that these techniques are completely opposed to daily techniques guided by the habits of the body. ${ }^{49}$ For this, daily behaviour should be analysed very well. Daily techniques are based on the principle of minimum energy, because in daily life, behaviours are the result of habits and are spontaneous. In extra-daily technique, even the slightest movement contains maximum energy. However, the extra-daily technique should not be confused with "techniques of virtuosity" based on the inaccessibility of the body, which have completely lost contact with the reality observed in acrobatics:

The purpose of the body's daily techniques is communication. The techniques of virtuosity aim for amazement and the transformation of the body. The purpose of extra-daily techniques, on the other hand, is information: they literally put the body in-form. Herein lies the essential difference which separates exta-daily techniques from those which merely transform the body. ${ }^{50}$

The knowledge transferred by extra-daily technique constitutes the quality of the relationship between the actor and the spectator. The movement performed on the stage becomes an action involving the impulses and the spine, thus opening the way to communicate with the spectator beyond affecting them.

The foundations of the actor's scenic behaviour are closely related to the concepts of organicity, impulse, and sats as well as to those of recurring principles. Organicity defines the quality of the fictionalized but true nature of the scenic bios of the actor. It is an essential quality for the spectator to believe unconditionally in the performance on the stage. ${ }^{51}$ The directors and their methods diversify in terms of the road maps they have developed for how the actor can achieve this effect. For Barba, the actions performed on the stage in order to create an organic effect or the choices made during the montage may be real, although not rational. Creating true life on the stage is possible with the organic nature of the action. Barba states that if the action is organic, the spectator believes in it and if they believe, it is real. ${ }^{52}$ So it's up to the actors to create an organic effect:

Organic effect means the capacity to make the spectator experience a body-in-life performing real actions, maybe not intelligible but coherent. The actor's main task is not to be organic but to appear organic to the eyes and senses of the spectator. ${ }^{53}$

In order to have an organic effect on the stage, the actor must be able to artificially recreate the spontaneity of a living organism. For this the actor must first develop an awareness of his/

48 Barba, The Paper Canoe: A Guide to Theatre Anthropology, 16.

49 Barba and Savarese, Dictionary of Theatre Anthropology: Secret Art of The Performer, 7.

50 Ibid., 8 .

51 Ibid., 206.

52 Eugenio Barba, Odin Week 2019 Speeches from Workshops and Seminars, Ed. Dila Okuş (Holstebro: 2019).

53 Barba and Savarese, Dictionary of Theatre Anthropology: Secret Art of The Performer, 206. 
her presence. With the disappearance of the dichotomy between the actor's daily life and scenic presence, the actor's behaviour automatically becomes a part of her scenic life. Therefore, the extra-daily technique ceases to be an artificial imitation "used" by the actor's body and becomes the form of the organic life of the living body on the stage.

The impulse and sats are essential components of the actor's level of expression. Where impulse explains the starting moment of performance of the real actions, sats explains the rhythmic composition of this performance. In the last years of his life, Stanislavski conducted studies that drew attention to the link between organic action and impulse. Grotowski on the other hand deepened the work of Stanislavski and conducted research on impulses as the starting point of physical actions. Barba also took this path opened by Grotowski and put the impulses that form the basis of the action at the center of actor training. While emphasizing the necessity of real action to create change in space and in the actor, he argues that the intention that will create this change first appears with impulse:

To act, in the theatre, means to intervene in time and space in order to change and to be changed. The impulse of an action, that is, the "movement of intention" begins in the spinal column. The energy necessary to give rise to precise actions is concentrated in the torso and withheld as an impulse. The actions are born here. One can see that performers are working with actions when even their trunks also execute them in miniature. Arms, hands and fingers are extensions, waiting to intervene. ${ }^{54}$

Sats shows the moment when the energy carried by the actor ready to act is suspended. Roberta Carreri, an Odin Theatre actress describes sats in her book On Training and Performance: Traces of an Odin Actress as follows:

One word which Eugenio used and still uses repeatedly during the work is sats, which is the Norwegian word for "impulse".

I can also define sats as the intention to accomplish a precise action. In the moment I accumulate the necessary mental energies, which are consequently also physical, to execute a one-metre-long leap, I enter a position of sats. I am not in sats position if my legs are fully extended. To be in sats position allows me to react and change direction at any moment. It allows me to be unpredictable. Being in sats position implies being present in the moment. ${ }^{55}$

While working with the actor on the action, both Stanislavski and Meyerhold felt the need to apply the concepts that regulate the expressive level of the action. As a technical term of the Odin Theatre it is possible to consider sats which means to prepare for action, as identical to Stanislavski's concept of standing in the correct rhythm. ${ }^{56}$ Meyerhold's works also develop

54 Barba, The Paper Canoe: A Guide to Theatre Anthropology, 161.

55 Roberta Carreri, On Training and Performance: Traces of an Odin Actress, trans. Frank Camilleri (New York: Routledge, 2014), 27.

56 Barba and Savarese Dictionary of Theatre Anthropology: Secret Art of The Performer, 92. 
concepts that explain this moment of pause, such as the term of predigra, which means preacting, used to describe the moment of tension resulting in the action. Another term used by Meyerhold is okatz. Okatz describes the point at which stopping and continuing come together, where one movement ends and another begins.

Eugenio Barba, states that in order to be able to talk about an artistic process, reality must be alienated in scenic life, and this is common in all artistic forms. ${ }^{57}$ Alienation does not exclude the concept of organicity, because the alienation of reality and its taking on a new reality eliminates the questions of why and how to find the equivalent in daily codes. The principle of equivalence established as a result of Theatre Anthropology research, describes the process followed while alienating a reality in theatre.

Extra-daily expression of a reality is possible through the transposition of a reality into another reality. The reality conveyed by the image that the actor sets out is transformed during the performance of the action. The actor transforms the reality that belongs to his/her inner space, that is the reaction, into the common space, that is, the extra-daily stage level shared with the spectator and other actors. This transposition is possible by performing the equivalent of the action that is taking place in the actor's inner space. In the process of transforming daily reality into scenic reality, reality is alienated and a new and coherent reality is constructed. The principle of equivalence provides the organic effect by establishing the equivalence relationship between reality and scenic reality.

The main goal of actor training is to develop the skills that can act with this logic in the performer. Therefore, what the actor learns during the exercises, as Grotowski emphasized for his own work, is not gymnastics, but the ability to control impulses in order to build a new way of behaviour. ${ }^{58}$ Barba argues that two sources of actor training are "the use of learned body techniques designed to break the performer's daily responses" and "codification of principles which dictate the use of energy during performance". ${ }^{59}$ These are also the sources of extra-daily scenic behaviour of the actor. The training carried out by the actors at the Odin Theatre consist of exercises that enable them to embody the recurring principles. The content of the exercise can vary according to the tendencies and needs of each actor, as long as this goal remains common. The body, which has gained an extra-daily scenic behaviour language as a result of the exercises performed by the actors themselves, is able to apply the principles while performing the actions in improvisation for the performance.

57 Eugenio Barba, Odin Week 2019 Speeches from Workshops and Seminars.

58 Ibid.

59 Hodge, Actor Training, xxiii. 


\section{Conclusion}

All of the directors whose methods have been examined throughout this paper draw attention to the need for the actor to set aside daily behaviour on the stage and develop a manner of behaviour belonging to the stage. The similarity between the formal appearance in the staging required by the theatre aesthetics which the director wants to create and daily reality, determines the character of the actor's extra-daily technique. Meyerhold and Grotowski clearly state that in their works on acting that the actor should put aside his/her daily behaviour. The scenic behaviour of Stanislavski's actor is formally more similar to daily reality than the scenic behaviour of Barba's actor, yet even when the actor plays with a realistic approach, the scenic behaviour carries an extra-daily quality as s/he puts aside daily behaviour. This is because in extra-daily scenic behaviour, it is not the rational meaning of the action that is extra-daily, but the way of performing it. Stanislavski developed a method by which actions on the stage can manifest with the same liveliness in each repetition. This is a situation that is not possible in daily life but can only be realized with a certain technique. Meyerhold sought ways to emphasize the essence of situations with theatrical means. Grotowski developed a way of behaviour for his actors beyond the social masks. Barba tries to draw attention to the commonality of the human condition beyond the habitual behaviour of the individual. The reason for Barba's emphasis on extra-daily technique is that this approach provides an opportunity to intervene in daily habits and habituated behaviour. This dramaturgical approach emerges from the unity of all levels of organization of the performance. However, the detailed work carried out on the level of organic dramaturgy that expresses the actor's activity is shaped by this dramaturgical approach. Revealing the relationship between the technical methods followed in the training of actors and the overall dramaturgical preferences of the director or the group adds an observable and measurable quality to the technique. This ensures that the work carried out in the practical field can be followed and developed with a scientific approach. The work of theatre people who contribute to the development of the extra-daily technique can undoubtedly be expanded. It is possible to enrich a similar work by including the works of different directors and actors. With similar studies to be carried out over the relationship between the director's purpose and the actor training, the data on why the spectator watches and how they experience the performances performed with an extra-daily technique will increase, and it will be possible to catch clues as to why both performers and spectators need art and theatre today. 
Peer-review: Externally peer-reviewed.

Conflict of Interest: The author has no conflict of interest to declare.

Grant Support: The author declared that this study has received no financial support.

Hakem Değerlendirmesi: Dış bağımsız.

Çıkar Çatışması: Yazar çıkar çatışması bildirmemiştir.

Finansal Destek: Yazar bu çalıșma için finansal destek almadığını beyan etmiștir.

\section{BIBLIOGRAPHY / KAYNAKÇA}

Bablet, Denis. “Actor's Technique”, In Towards a Poor Theatre. Edited by Eugenio Barba, 205-225. New York: Routledge, 2002.

Barba, Eugenio. "Grandfathers, Orphans, and the Family Saga of European Theatre", New Theatre Quarterly 19/2 (2003). 108-118.

Barba, Eugenio. "The Essence of Theatre", TDR(1988-) 46/3 (2002). 12-30.

Barba, Eugenio. The Paper Canoe: A Guide to Theatre Anthropology, Translated by Richard Fowler. New York: Routledge, 2002.

Barba, Eugenio. "Letter From Barba”, The Drama Review: TDR 19/4 (1975). 47-57.

Barba, Eugenio. "The Theatre's New Testament”, In Towards a Poor Theatre. Edited by Eugenio Barba, 2755. New York: Routledge, 2002.

Barba, Eugenio. On Directing and Dramaturgy, Burning the House, Translated by Judy Barba. New York: Routledge, 2010.

Barba, Eugenio and Savarese, Nicola. Dictionary of Theatre Anthropology: Secret Art of The Performer, Translated by Richard Fowler. London: Routledge, 2006.

Barba, Eugenio. Odin Week 2019 Speeches from Workshops and Seminars, Edited by Dila Okuş. Holstebro: 2019.

Barba, Eugenio ve Savarese, Nicola. The Five Continents of Theatre: Facts and Legends about the Material Culture of the Actor, Translated by T. H. Simpson. Boston: Brill Sense, 2019.

Benedetti, Jean. Stanislavski: An Introduction. New York: Routledge, 2005.

Carreri, Roberta. On Training and Performance: Traces of an Odin Actress, Translated by Frank Camilleri. New York: Routledge, 2014.

Fragments From Training at Teatr-Laboratorium, Director Torgeir Wethal. Holbstebro: Odin Teatret Archives, 1972.

Gorchakov, Nikolai M.. Stanislavski Directs. New York: Minerva Press, 1954.

Grotowski, Jerzy. “He Wasn’t Entirely Himself”, In Towards a Poor Theatre. Edited by Eugenio Barba, 117127. New York: Routledge, 2002.

Grotowski, Jerzy. "Towards a Poor Theatre", In Towards a Poor Theatre. Edited by Eugenio Barba, 15-27. New York: Routledge, 2002.

Grotowski, Jerzy. "Methodical Exploration", In Towards a Poor Theatre. Edited by Eugenio Barba, 127-133. New York: Routledge, 2002. 
Hodge, Alison. Actor Training. New York: Routledge, 2010.

Hoover, Marjorie L.. Meyerhold: The Art of Conscious Theater. Amherst: University

Massachusetts Press, 1974.

Karaboğa, Kerem. Oyunculuk Sanatında Yöntem ve Paradoks. İstanbul: Habitus Yayıncılık, 2018.

Kumiega, Jane. The Theatre of Grotowski. New York: Methuen, 1985.

Law, Alma ve Gordon, Mel.. Meyerhold, Eisenstein and Biomechanics: Actor Training in Revolutionary Russia, Jefforson: McFarland\&Company, 1996.

Meyerhold, Vsevolod. Meyerhold on Theatre. Edited by Edward Braun. London: Bloomsbury Methuen Drama, 2016.

Moore, Sonia. The Stanislavski System, The Professional Training of an Actor. New York: Penguin Books, 1984.

Richards, Thomas. At Work With Grotowski on Physical Actions. London/New York: Routledge, 1995.

Stanislavski, Konstantin. "Stanislavski’nin Mirası", Translated by Metin Göksel and Gamze Ahıskanlı, Mimesis Tiyatro/Çeviri-Araştırma Dergisi 3 (1990), 125-166.

Stanislavski, Konstantin. An Actor Prepares, Translated by Elizabeth Reynolds Hapgood. London: Bloomsbury Publishing, 2014.

Watson, Ian. "Eastern and Western Influences on Performer Training at Eugenio Barba's Odin Teatret", Asian Theatre Journal 5/1 (1988), 49-60.

Whyman, Rose. Stanislavsky System of Acting, Legacy and Influence in Modern Performance. New York: Cambridge University Press, 2008.

Worral, Nick. Modernism to Realism on the Soviet Stage. New York: Cambridge

University Press, 1989. 
